\title{
Validation of the Brazilian version of WHODAS 2.0 in patients on hemodialysis therapy
}

\author{
Validação da versão brasileira de WHODAS \\ 2.0 em pacientes em hemodiálise
}

\section{Validación de la versión brasileña de WHODAS 2.0 en pacientes en terapia de hemodiálisis}

\author{
Shamyr Sulyvan Castro ${ }^{[a]}$, Camila Ferreira Leite $^{[a]}$, Juliana Elisa Baldin ${ }^{[b]}$, Marilita Falangola Accioly ${ }^{[b]}$ \\ [a] Universidade Federal do Ceará (UFC), Fortaleza, CE, Brazil \\ [b] Universidade Federal do Triângulo Mineiro (UFTM), Uberaba, MG, Brazil
}

\section{Abstract}

Introduction: Chronic kidney disease and hemodialysis normally have an impact on the functioning. Objective: To validate the Brazilian version of the World Health Organization Disability Assessment Schedule 2.0 in individuals with chronic kidney disease on hemodialysis treatment. Methods: The 36-item version was applied to interview 51 individuals with chronic kidney disease undergoing dialysis treatment. To ascertain the instrument's applicability, its internal consistency and test-retest stability were studied. To check the validity, a convergent/divergent analysis was performed. Results: The participants answered the questions on the main instrument at two timepoints and on the World Health Organization Quality of Life Abbreviated instrument and the Kidney Disease Quality of Life - Short FormTM 1.3 once each. Cronbach's

*SSC: PhD, e-mail: shamyrsulyvan@gmail.com

CFL: PhD, e-mail: camilafl.fisio@gmail.com

JEB: undergrad, e-mail: juliana.bal.din@hotmail.com

MFA: PhD, e-mail: marilitafisio@gmail.com 
$\alpha$ coefficient was appropriate in all domains except the "Getting along" domain. The test-retest coefficients were above the recommended value $(>0.70)$. Convergent and divergent validity analysis also showed consistent results by correlation coefficient assessment. Conclusion: The instrument is valid and reliable. This study supports the use of the questionnaire by presenting its appropriate psychometric properties. We suggest that some care should be taken specifically in the sexual questions of the "Getting along" domain.

Keywords: Reliability and Validity. Disability Evaluation. Brazil.

\section{Resumo}

Introdução: A doença renal crônica e a hemodiálise normalmente têm um impacto na funcionalidade. objetivo: Validar a versão brasileira do World Health Organization Disability Assessment Schedule - WHODAS 2.0 em indivíduos com doença renal crônica em tratamento de hemodiálise. Métodos: A versão de 36 itens foi aplicada por entrevista em 51 indivíduos com doença renal crônica submetidos a tratamento de hemodiálise. Para verificar a aplicabilidade do instrumento, sua consistência interna e estabilidade teste-reteste foram estudadas. Para verificar a validade, a análise convergente/divergente foi realizada. Resultados: Os participantes responderam às perguntas do instrumento principal em dois momentos distintos no tempo, e do instrumento abreviado sobre Qualidade de Vida da Organização Mundial de Saúde e do questionário Qualidade de Vida com Doença Renal - Short FormTM 1.3 uma vez cada u m. O coeficiente $\alpha$ de Cronbach foi apropriado em todos os domínios, exceto o domínio "Relações Interpessoais". Os coeficientes teste-reteste estavam acima do valor recomendado $(>0,70)$. A análise de validade convergente e divergente também mostrou resultados consistentes pela avaliação dos coeficientes de correlação. Conclusão: $O$ instrumento é válido e confiável. Este estudo apoia o uso do instrumento pela apresentação das suas propriedades psicométricas apropriadas. Sugerimos que alguns cuidados devem ser tomados especificamente nas questões sobre relações sexuais.

Palavras-chave: Confiabilidade e Validade. Avaliação de Deficiência. Brasil.

\section{Resumen}

Introducción: La enfermedad renal crónica y la hemodiálisis normalmente tienen un impacto en el funcionamiento. Propósito: Validar la versión brasileña del World Health Organization Disability Assessment Schedule - WHODAS 2.0 en individuos con enfermedad renal crónica en tratamiento de hemodiálisis. Métodos: La versión de 36 ítems se aplicó a 51 personas con enfermedad renal crónica sometidas a tratamiento de diálisis. Para determinar la aplicabilidad del instrumento, se estudió su consistencia interna y estabilidad testretest. Para verificar la validez, se realizó el análisis convergente / divergente. Resultados: Los participantes respondieron las preguntas sobre el instrumento principal en dos puntos de tiempo y sobre el instrumento abreviado de calidad de vida de la Organización Mundial de la Salud y la calidad de vida de la enfermedad renal-Short FormTM 1.3 una vez. El coeficiente alpha de Cronbach fue apropiado en todos los dominios, excepto en el dominio "Getting along". Los coeficientes de prueba-reprueba estaban por encima del valor recomendado $(>0,70)$. El análisis de validez convergente y divergente también mostró resultados consistentes por la evaluación del coeficiente de correlación. Conclusión: El instrumento es válido y confiable. Este estudio apoya el uso del instrumento por presentación de sus las propiedades psicométricas apropiadas. Sugerimos que se tenga algo de cuidado específicamente en las cuestiones sexuales del dominio de la apropiación.

Palabras clave: Confiabilidad y Validez. Evaluación de la Discapacidad. Brasil. 


\section{Introduction}

Chronic kidney disease (CKD) is an important public health problem with increasing incidence in low-, middle-, and high-income nations alike. Given projected increases in the prevalence of risk factors for chronic kidney disease (including diabetes, hypertension, and cardiovascular disease), the prevalence of chronic kidney disease in lower-income countries is also expected to dramatically increase over the next two decades [1].

CKD is characterized by kidney injury with progressive and irreversible loss of kidney functions (glomerular, tubular and endocrine) [2]. Clinically, individuals with CKD that progresses to end-stage renal disease have the treatment option of hemodialysis, which clears the blood of undesirable substances [3]. Accordingly, hemodialysis is viewed as an important strategy to prolong the life and improve the living conditions of individuals with CKD; nonetheless, it does not represent a curative strategy [4]. In fact, people with CKD treated with hemodialysis have poorer physical and functional abilities than healthy individuals [5]. Patients with chronic renal failure who are dependent on dialysis show physical dysfunction that is caused not only by a lack of muscle but also by a decline in the function of the muscles [6]. Furthermore, comorbid conditions such as heart failure, peripheral vascular disease and diabetes mellitus might contribute to a worse functional status [6].

The functioning changes of individuals with CKD undergoing dialysis treatment can also be explained by the changes in volumetric components and the impaired ventilatory capacity that are common in these individuals, as detected in pulmonary function tests $[7,8]$. The reduction in the strength and endurance of the respiratory muscles, likely due to uremic myopathy [8], is probably another cause of disability. In this context, the decline in the functional capacity of these individuals is caused by multiple factors, including associated cardiovascular, respiratory and muscular problems, in which the ability to capture, transport and use 02 may be diminished [8].

The limitations related to CKD corroborate the need for disability and functioning assessment. Taking into account that chronic diseases have shown increasing prevalence and incidence along with the increase in life expectancy, disability and functioning assessment is currently a particularly important subject $[9,10]$. In this context, in 2001, the World Health Organization (WHO) published the International Classification of Functioning, Disability and Health (ICF) [10,11]. The ICF conceives of functioning as a result of the interactions of its components, namely, "health conditions", "body functions and structures", "activities", "participation", "personal" factors and "environmental" factors, and stands out in that it conceptualizes functioning as a biopsychosocial concept, moving beyond the biomedical model [11]. Since the publication of the ICF, several tools related to and derived from the ICF have been created by the WHO, with the World Health Organization Disability AssessmentSchedule (WHODAS) 2.0 among them. This is a generic tool that aims to assess health and functioning and that could be more suitable for application than the ICF in certain situations. The WHODAS can be used at the population and clinical levels [12 - 14]' and it has been presented as a tool to produce standardized disability levels and profiles for assessed subjects and is straightforwardly related to the ICF concepts [15]. Thus, the WHODAS 2.0 is under consideration as an assessment tool based on the ICF framework [16].

In order for a tool to be reliably used in the measurement of a health event, it must be validated. This process involves the verification of psychometric properties as internal and external consistency, and reproducibility and responsiveness, as well [17].

The use of an instrument based on the ICF could offer the opportunity to assess the functioning of people with CKD by providing a multifactorial overview, allowing health professionals to perform specific interventions focused not only on the medical symptoms but also on improving patients' functioning. Therefore, the aim of the present research was to study the psychometric properties of the Brazilian version of the WHODAS 2.0 as a tool to assess the functioning of people with CKD on hemodialysis therapy.

\section{Methods}

\section{Participants}

In total, 51 patients with CKD on hemodialysis therapy participated in this study. The selection process began by collecting a convenience sample of patients from three hospitals that offer hemodialysis therapy, in a city of approximately 350,000 inhabitants. The inclusion criteria adopted were a medical diagnosis of CKD, being on hemodialysis treatment and being over 18 years old. Patients who were unable to answer the interview questions were excluded. The patients' characteristics are summarized in Table 1. A written informed consent document was obtained from each participant, and the 
project was approved by the Ethical Committee of the Universidade Federal do Triângulo Mineiro (UFTM), Brazil (protocol 36151314.7.0000.5154).

Procedures

A trained interviewer collected data at two different timepoints separated by a seven-day interval, and all the interviews were carried out in specific rooms, respecting each patient's privacy. Information was tabulated using the Excel program.

Data collection

Two trained interviewers used the 36-question version of the WHODAS to collect the data from February to September, 2016. The interviews were always carried out in a private room where the patients sought hemodialysis and lasted on average 40 minutes the first time. Figure 1 shows the data collection timeline and the tools used, as this study aimed to check the test-retest reliability. The time between the two interviews 7 days) was recommended by the WHODAS Manual [15]. Figure 1 also presents the moment of data collection using each instrument. No values were missing from the data collection.

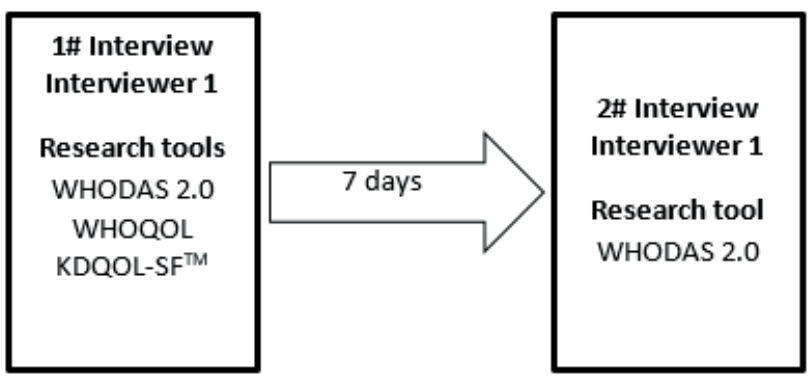

Figure 1 - Timeline of the data collection, interviews and tools used.

\section{Outcome measures}

For this research, the following instruments were used: the WHODAS 2.0, the World Health Organization Quality of Life Abbreviated (WHOQOL)-BREF, and the Kidney Disease Quality of Life Short Form (KDQOLSFTM) 1.3. The WHOQOL-BREF and the KDQOLSFTM were selected because they are tools that assess constructs close to those in the WHODAS 2.0.

The WHODAS 2.0 is a generic functioning assessment questionnaire with a Brazilian version [16]. The instrument is composed of 36 questions encompassing six life domains: Cognition, which addresses understanding and communicating (six items); Mobility, which focuses on moving and getting around (five items); Self-care, which is concentrated on hygiene, dressing, eating and independent living (four items); Getting along, which examines interacting with other people (five items); Life activities, which is directed toward domestic responsibilities, leisure, work and school (eight items); and Participation, which is related to joining in community activities (eight items). Each question has five alternatives as possible answers, ranging from 1 , meaning no difficulty, to 5 , meaning extreme difficulty or inability to do the activity. Domain and general scores are computed, ranging from 0 to 100 , with higher scores reflecting worse levels of functioning. There are three versions of the WHODAS, with 36,12 , and $12+24$ questions. In addition, three different application models can be used: one is by an interviewer, another is self-administered, and the last collects the data through a proxy [16]. The WHODAS has been validated around the world for assorted groups, such as patients with chronic disease [18], osteoarthritis [19], inflammatory arthritis [20], rheumatoid arthritis [21], multiple sclerosis [22], systemic sclerosis [23], Huntington disease [24], schizophrenia [25], bipolar disorders [26], and stroke [27]; people in rehabilitation [28]; and adults with acquired hearing loss [29], among others. However, none of these validations was performed in Brazil. It should be noted that no papers validating the instrument for use in patients with CKD are available either.

The WHOQOL-BREF is an abbreviated version of the World Health Organization Quality of Life (WHOQOL)-100 instrument and has 26 items covering four quality-of-life domains: physical (seven items), psychological (six items), social (three items) and environmental (eight items), with two more general questions about health and quality of life [30]. The WHOQOL-BREF has a Likert response scale varying from 1 to 5 , and scores for each domain as well as a total score can be calculated [31]. These scores are represented along a linear scale from 0 to 100, where higher scores reflect better quality of life [32]. The WHOQOL-BREF has been translated and validated for use in Brazil [33].

The KDQOL-SFTM 1.3 is a disease-specific questionnaire created to assess the quality of life of people with end-stage renal disease [34]. This questionnaire includes questions from the SF-36 instrument and disease-specific components related to kidney disease and can be used to assess patients on dialysis [35]. The KDQOL-SFTM 1.3 is composed of 43 items related to kidney disease, spanning 11 domains: symptom/problem list (12 questions), effects of kidney 
disease (eight questions), burden of kidney disease (four questions), cognitive function (three questions), quality of social interaction (three questions), sexual function (two questions), sleep (four questions), social support (two questions), work status (two questions), patient satisfaction (one question), and dialysis staff encouragement (two questions). In addition, the SF36 questions are grouped into eight domains: physical function (ten questions), role limitations caused by physical problems (four questions), role limitations caused by emotional problems (three questions), pain (two questions), general health perceptions (five questions), social function (two questions), emotional well-being (five questions), and energy/fatigue (four questions). The final item is related to overall health. The results of the SF-36 instrument are used to generate a physical composite summary score (physical function, role/physical, pain, and general health) and a mental composite summary score (role/emotional, emotional wellbeing, energy, and social function). The scores for each dimension range from 0 to 100 , and higher scores reflect better quality of life [36]. The KDQOL-SFTM 1.3 has been translated and validated for use in Brazil [37].

\section{Statistical analysis}

All statistical analyses are described below and were carried out using the program Stata 13. A statistical significance level of $5 \%$ was used.

Reliability

Cronbach's coefficient was used to assess the internal consistency [38] with clustering of the questions in each domain. The test-retest stability was analyzed based on the intra-class correlation coefficient (ICC), for which values of 0.70 and at least 0.85 are recommended for group-level analysis and individual use, respectively [19]. The WHODAS variables from the firstand second interviews were compared.

\section{External validity}

Spearman's rank correlation coefficient was used to test the external validity of the WHODAS 2.0, and the WHOQOL-BREF and the KDQOL-SF 1.3 were adopted to test the convergent and divergent validity by comparing the related and unrelated domains, respectively. Considering the convergent validity, as our a priori hypothesis, we assumed that the following domains were related: a) Cognition from the WHODAS and the KDQOL; b) Mobility from the WHODAS, Physical from the WHOQOL, and Physical and Energy/Fatigue from the KDQOL; c) Getting Along from the WHODAS and Sexual Function from the KDQOL; d) Life Activities from the WHODAS and Physical from the WHOQOL; e) Selfcare from the WHODAS and Physical from the WHOQOL and the KDQOL; f) Participation from the WHODAS and Social from the WHOQOL and the KDQOL; and g) the total scores on the WHODAS and the WHOQOL.

\section{Results}

A total of 51 people with CKD undergoing hemodialysis were recruited for this research; a description of the sample is provided in Table 1.

Table 1 - Study sample description

(to be continue)

\begin{tabular}{lcc}
\hline Variable & $\mathbf{n}(\mathbf{5 1 )}$ & \% (100.00) \\
\hline Gender & 31 & 60.78 \\
Male & 20 & 39.22 \\
Female & & \\
Marital status & 16 & 31.37 \\
Never married & 18 & 35.29 \\
Currently married & 1 & 1.96 \\
Separated & 5 & 9.80 \\
Divorced & 9 & 17.65 \\
Widowed & 2 & 3.92 \\
Cohabiting & & \\
\hline
\end{tabular}


Table 1 - Study sample description

\begin{tabular}{|c|c|c|}
\hline \multicolumn{3}{|l|}{ Work status } \\
\hline Retired & 41 & 80.39 \\
\hline \multirow[t]{2}{*}{ Other } & 10 & 19.61 \\
\hline & Mean & Standard deviation \\
\hline Age (years) & 54.58 & 15.84 \\
\hline Years of formal study & 7.45 & 5.66 \\
\hline Individual income (minimum monthly wage) & 1.54 & 1.7 \\
\hline Time to diagnosis (months) & 71.05 & 59.16 \\
\hline Time to treatment (months) & 59.93 & 59.20 \\
\hline Dry weight (kg) & 67.73 & 17.97 \\
\hline Initial weight (kg) & 70.20 & 18.53 \\
\hline Final weight (kg) & 67.61 & 18.08 \\
\hline Initial urea & 129.728 & 39.54 \\
\hline Final urea & 47.89 & 27.24 \\
\hline Potassium & 5.43 & 0.86 \\
\hline \multicolumn{3}{|l|}{ WHODAS 2.0} \\
\hline Cognition & 11.17 & 15.57 \\
\hline Mobility & 31.12 & 27.99 \\
\hline Self-care & 6.27 & 16.48 \\
\hline Getting along & 8.33 & 12.01 \\
\hline Life activities & 10.19 & 14.69 \\
\hline Participation & 23.61 & 18.86 \\
\hline Total & 15.61 & 12.33 \\
\hline \multicolumn{3}{|l|}{ WHOQOL-BREF } \\
\hline Physical & 50.28 & 17.61 \\
\hline Psychological & 74.01 & 14.56 \\
\hline Social & 72.06 & 16.98 \\
\hline Environmental & 72.92 & 15.85 \\
\hline Total & 67.31 & 12.16 \\
\hline \multicolumn{3}{|l|}{ KDQOL-SF ${ }^{\mathrm{TM}} 1.3$} \\
\hline Symptom/problem list & 71.65 & 17.06 \\
\hline Effects of kidney disease & 70.46 & 19.95 \\
\hline Burden of kidney disease & 55.02 & 28.55 \\
\hline Work status & 8.82 & 25.89 \\
\hline Cognitive function & 93.72 & 12.02 \\
\hline Quality of social interaction & 87.84 & 16.42 \\
\hline Sexual function & 94.07 & 14.65 \\
\hline Sleep & 65.13 & 25.61 \\
\hline Social support & 83.66 & 21.98 \\
\hline Dialysis staff encouragement & 88.72 & 24.27 \\
\hline Overall health & 61.96 & 22.89 \\
\hline Patient satisfaction & 63.07 & 17.73 \\
\hline Physical functioning & 54.11 & 31.09 \\
\hline
\end{tabular}


Table 1 - Study sample description

(conclusion)

\begin{tabular}{lll}
\hline Role/physical & 26.47 & 38.21 \\
Pain & 64.31 & 36.11 \\
General health & 52.64 & 27.84 \\
Emotional well-being & 65.01 & 22.89 \\
Role/emotional & 70.58 & 43.02 \\
Social function & 83.08 & 27.59 \\
Energy/fatigue & 50.49 & 25.77 \\
SF-12 physical composite & 36.35 & 11.13 \\
SF-12 mental composite & 50.24 & 10.04 \\
\hline
\end{tabular}

The reliability of the instrument was assessed by analyzing the internal consistency and the test-retest stability by domains and total scores, as shown in Table 2. It should be highlighted that in the first analysis of the internal consistency of the Getting Along domain, all questions were considered. However, a low Cronbach's $\alpha$ coefficient was found (0.47). Further analysis was then carried out, aiming to test the individual influence of each question in this domain. This process consisted of excluding one question at a time. By deleting two questions about intimate relationships and sexual activity, a higher Cronbach's $\alpha$ coefficient was achieved (0.65).

Table 2 - Cronbach's $\alpha$ and ICCs according to the WHODAS 2.0 domains

\begin{tabular}{ccc}
\hline WHODAS 2.0 domain* & Cronbach's $\alpha$ & ICC (95\%) - Test-retest \\
\hline Cognition & 0.75 & $0.98(0.94-0.99)$ \\
Mobility & 0.81 & $0.97(0.94-0.99)$ \\
Self-care & 0.80 & $0.95(0.86-0.98)$ \\
Getting along & $0.47 / 0.65$ & $0.96(0.88-0.99)$ \\
Life activities & 0.90 & $0.96(0.90-0.99)$ \\
Participation & 0.77 & $0.98(0.95-0.99)$ \\
Total & 0.89 & $0.99(0.98-0.99)$ \\
\hline
\end{tabular}

Note: * The domains for work and school activities were not analyzed.

The external validity was tested by analyzing the correlation of the WHODAS domains with the domains of two other instruments, namely, the WHOQOL-BREF and the KDQOL-SFTM 1.3. Table 3 shows the correlation coefficients for the WHODAS domains and the domains of the other instruments along with their respective statistical significance levels.

Table 3 - Correlation coefficient matrix among the WHODAS 2.0, WHOQOL-BREF and KDQOL-SF ${ }^{\mathrm{TM}} 1.3$ domains

\begin{tabular}{|c|c|c|c|c|c|c|c|}
\hline \multirow[t]{2}{*}{ Instrument/Domain } & \multicolumn{7}{|c|}{ WHODAS domains } \\
\hline & Cognition & Mobility & Self-care & $\begin{array}{c}\text { Getting } \\
\text { along }\end{array}$ & $\begin{array}{c}\text { Life } \\
\text { activities }\end{array}$ & Participation & Total \\
\hline \multicolumn{8}{|l|}{ WHOQOL-BREF } \\
\hline Physical & $-0.2802^{\star}$ & $-0.6293^{*}$ & $-0.5908^{\star}$ & -0.2279 & $-0.6774^{\star}$ & $-0.3954^{*}$ & $-0.6903^{*}$ \\
\hline Psychological & $-0.4597^{*}$ & $-0.3427^{\star}$ & $-0.4981^{*}$ & -0.1364 & $-0.3719^{\star}$ & $-0.4510^{\star}$ & -0.5581 \\
\hline Social & $-0.4042^{\star}$ & -0.1612 & -0.2675 & -0.2197 & -0.1900 & $-0.4758^{*}$ & $-0.3963^{*}$ \\
\hline Environmental & $-0.5207^{\star}$ & $-0.3044^{*}$ & $-0.3403^{\star}$ & $-0.3829 *$ & -0.2654 & $-0.4632^{\star}$ & $-0.5314^{*}$ \\
\hline Total & $-0.5518^{*}$ & $-0.5843^{*}$ & $-0.6050^{\star}$ & $-0.3161^{*}$ & -0.5611 & $-0.6083^{*}$ & $-0.7895^{\star}$ \\
\hline
\end{tabular}


Table 3 - Correlation coefficient matrix among the WHODAS 2.0, WHOQOL-BREF and KDQOL-SF ${ }^{\mathrm{TM}} 1.3$ domains

(conclusion)

\begin{tabular}{|c|c|c|c|c|c|c|c|}
\hline \multirow[t]{2}{*}{ Instrument/Domain } & \multicolumn{7}{|c|}{ WHODAS domains } \\
\hline & Cognition & Mobility & Self-care & $\begin{array}{l}\text { Getting } \\
\text { along }\end{array}$ & $\begin{array}{c}\text { Life } \\
\text { activities }\end{array}$ & Participation & Total \\
\hline \multicolumn{8}{|l|}{$\mathrm{KDQOL}^{-S F^{T M}} 1.3$} \\
\hline Symptom/problem list & $-0.4475^{\star}$ & $-0.4727^{\star}$ & $-0.3345^{\star}$ & $-0.2786^{\star}$ & $-0.4120^{*}$ & $-0.4812^{*}$ & $-0.5947^{*}$ \\
\hline Effects of kidney disease & -0.1593 & -0.1354 & $-0.2872^{\star}$ & -0.2547 & -0.1580 & $-0.5834^{*}$ & $-0.3759^{\star}$ \\
\hline Burden of kidney disease & $-0.3291^{*}$ & $-0.4310^{\star}$ & $-0.4257^{\star}$ & $-0.3284^{*}$ & $-0.3858^{*}$ & $-0.7316^{*}$ & $-0.6747^{*}$ \\
\hline Work status & -0.0651 & 0.0326 & 0.0993 & 0.0145 & 0.0342 & $0.2873^{*}$ & 0.1133 \\
\hline Cognitive function & $-0.6308^{*}$ & -0.3862 & -0.2388 & $-0.4209^{*}$ & $-0.3134^{*}$ & $-0.3223^{*}$ & $-0.5326^{*}$ \\
\hline $\begin{array}{l}\text { Quality of social } \\
\text { interaction }\end{array}$ & -0.1872 & 0.0029 & -0.1600 & -0.0715 & 0.1268 & -0.2310 & -0.0262 \\
\hline Sexual function & 0.1497 & -0.2279 & $-0.4742^{*}$ & $-0.6046^{\star}$ & -0.4360 & 0.2975 & -0.3204 \\
\hline Sleep & -0.438 & 0.0614 & 0.0432 & -0.0046 & 0.3218 & -0.1999 & -0.0168 \\
\hline Social support & -0.0519 & -0.0494 & $-0.4831 *$ & -0.3679 & -0.3964 & $-0.5068^{*}$ & -0.2831 \\
\hline $\begin{array}{l}\text { Dialysis staff } \\
\text { encouragement }\end{array}$ & -0.143 & -0.3540 & 0.0556 & 0.1751 & 0.1208 & -0.2612 & -0.3026 \\
\hline Overall health & -0.0832 & -0.2095 & $-0.3619^{*}$ & -0.0529 & -0.2491 & $-0.4937^{*}$ & $-0.3777^{*}$ \\
\hline Patient satisfaction & -0.2046 & -0.0799 & -0.0289 & -0.1475 & 0.0271 & -0.1049 & -0.1320 \\
\hline Physical functioning & $-0.2972^{\star}$ & $-0.8397^{\star}$ & $-0.4303^{\star}$ & -0.1596 & $-0.5823^{*}$ & -0.1566 & $-0.6703^{*}$ \\
\hline Role/physical & -0.1350 & -0.2733 & -0.2667 & $-0.3644^{*}$ & $-0.4136^{*}$ & -0.2532 & $-0.3227^{*}$ \\
\hline Pain & $-0.3285^{\star}$ & $-0.5392^{*}$ & -0.1996 & -0.2727 & $-0.2801^{*}$ & $-0.2953^{*}$ & $-0.5346^{*}$ \\
\hline General health & -0.2741 & $-0.5026^{\star}$ & $-0.3364^{*}$ & -0.2475 & $-0.3223^{*}$ & $-0.4796^{*}$ & $-0.5870^{*}$ \\
\hline Emotional well-being & $-0.2948^{\star}$ & $-0.2869 *$ & -0.2584 & -0.0590 & $-0.3028^{*}$ & $-0.4405^{\star}$ & $-0.4639 *$ \\
\hline Role/emotional & -0.2202 & -0.1127 & -0.2430 & $-0.4125^{\star}$ & $-0.3527^{*}$ & $-0.5547^{\star}$ & $-0.4067^{*}$ \\
\hline Social function & -0.0967 & -0.0831 & $-0.3402^{*}$ & $-0.2775^{\star}$ & -0.1874 & $-0.5513^{*}$ & $-0.3283^{*}$ \\
\hline Energy/fatigue & $-0.4512^{\star}$ & $-0.6347^{\star}$ & $-0.4434^{\star}$ & -0.1969 & $-0.4602^{\star}$ & $-0.3443^{*}$ & $-0.6540^{*}$ \\
\hline $\begin{array}{l}\text { SF-12 physical } \\
\text { composite }\end{array}$ & $-0.3388^{\star}$ & $0.7773^{\star}$ & $-0.4200^{*}$ & -0.2037 & $-0.5515^{\star}$ & $-0.2789 *$ & $-0.7022^{*}$ \\
\hline SF-12 mental composite & -0.2681 & -0.1637 & $-0.3399 *$ & -0.2176 & -0.3277 & $-0.6274^{*}$ & $-0.4702^{*}$ \\
\hline
\end{tabular}

Note: ${ }^{\star} p<.05$ (Spearman's correlation test).

\section{Discussion}

Currently, there is an abundance of functioning assessment tools for a variety of health conditions [39, 40]. However, it is of utmost importance to understand functioning according to the bio-psychosocial model, in line with the recommendations of the WHO, as presented by the published ICF. The ICF specifically proposes the comprehension of functioning according to its components: health conditions, body functions and structures, activity, participation and personal and environmental factors. Functioning in activities and participation is also considered [41]. In this context, the use of the WHODAS to assess functioning among people with CKD undergoing hemodialysis may be an opportunity to study and address functioning in the same way as that proposed by the ICF. In addition, with this tool, patients' functioning can be monitored throughout the treatment course in clinical and academic environments, allowing all possible aspects of functioning to be addressed via a more comprehensive approach. As with studies from other countries $[18,22,41,42]$, the validation of the Brazilian version of the WHODAS showed satisfactory psychometric properties, allowing the use of the tool to assess functioning in patients with CKD. However, care should be taken for effective use of the instrument, as discussed below. 
Reliability

The coefficients for the domains Cognition, Mobility, Self-care, Life Activities, and Participation were consistent with the findings of published studies with the same aims performed in other countries $[21,22,28$, 41, 43 - 45]. In contrast, the coefficient for the Getting Along domain may indicate that the information from this domain does not present the expected reliability. Following the pattern shown in a previous paper [22], the effect of each question was tested, and a higher Cronbach's $\alpha$ was found when two questions about intimate relationships and sexual activity were excluded from the analysis process. This finding demonstrates the sensitivity of the subject matter and led us to realize the need to carefully consider and plan the use of these questions when assessing functioning among people with CKD. The test-retest reliability showed high ICCs, in line with the literature $[18,23]$. These ICCs ensure reliability with repeated application in data collection for the assessment of functioning.

\section{Validity}

The correlation coefficients for the domains of the WHODAS, WHOQOL and KDQOL-SFTM 1.3 are presented in Table 3 , and the values are consistent with well-accepted values [46]. The Cognition domain of the WHODAS was correlated with the Cognition function domain from the KDQOL, the Mobility domain from the WHODAS showed correlation with the Physical WHOQOL domain and with the Physical and Energy/ Fatigue domains of the KDQOL, the Getting Along domain of the WHODAS correlated with the domain of Sexual Function of the KDQOL, the Life Activities domain from the WHODAS showed correlation with the Physical domain of the WHOQOL, and the domain total of the WHODAS showed correlation with that of the WHOQOL. A simple correlation (coefficient from 0.30 to 0.59 ) [46] was found when comparing the Selfcare domain of the WHODAS with the Physical domain of the WHOQOL and with the Physical functioning domain of the KDQOL, and the Participation domain of the WHODAS correlated with the Social domain of the WHOQOL and with the Social Function domain of the KDQOL. The results shown above support the convergent validity of the WHODAS.

To check the divergent validity, certain unrelated domains were chosen to illustrate this psychometric property. The Cognition domain of the WHODAS was not correlated with the Physical domain of the WHOQOL or with the Physical Functioning domain of the KDQOL, the
Mobility domain of the WHODAS showed no correlation with the Cognitive Function or Sleep domains of the KDQOL, the Self-care domain of the WHODAS was not correlated with the Cognitive Function or Sleep domains of the KDQOL, the Getting Along domain of the WHODAS showed no correlation with the Sleep or Work Status domains of the KDQOL, the Life Activities domain of the WHODAS was not correlated with the Sexual Function or Social Function domains of the KDQOL, and there was no correlation between the Participation domain of the WHODAS and the Sexual Function or Sleep domain of the KDQOL.

\section{Strengths and limitations}

The sample size is the main limitation of this study, considering that only 51 people participated in the validation process presented here. It is noteworthy that the frequency of people with CKD undergoing hemodialysis is low, complicating the collection of large samples. Furthermore, the geographical limitation could be another weakness of the study. However, it should be highlighted that this study makes a generic and ICF-based tool available to assess functioning in a group of people with very compromised health. The validation of the WHODAS will also allow clinicians and researchers to use the instrument, exploring all its domains and aspects and approaching the functioning in a comprehensive way and according to the WHO recommendations.

\section{Conclusion}

The WHODAS 2.0 is valid and reliable for use in patients with CKD undergoing hemodialysis. This study supports the use of the Brazilian version of the WHODAS 2.0 by presenting its appropriate psychometric properties. However, we suggest that the utility of the sexual questions in the Getting along domain requires further discussion.

\section{References}

1. Couser WG, Remuzzi G, Mendis S, Tonelli M. The contribution of chronic kidney disease to the global burden of major noncommunicable diseases. Kidney Int [Internet]. 2011 Dec;80(12):1258-70. Available from: http://www.sciencedirect.com/science/article/ pii/S0085253815550047 
2. Romão Junior JE. Doença Renal Crônica: Definição, Epidemiologia e Classificação. J Bras Nefrol. 2004;26(1):1-3.

3. Nascimento CD, Marques IR. Intervenções de enfermagem nas complicações mais freqüentes durante a sessão de hemodiálise: revisão da literatura. Rev Bras Enferm [Internet]. 2005 Dec;58(6):719-22. Available from: http://www.scielo.br/scielo.php?script=sci_ arttext\&pid=S0034-71672005000600017\&lng=pt\&n $\mathrm{rm}=\mathrm{iso} \&$ tlng $=\mathrm{pt}$

4. Locatelli F. Dose of dialysis, convection and haemodialysis patients outcome--what the HEMO study doesn't tell us: the European viewpoint. Nephrol Dial Transplant [Internet]. 2003 Jun 1;18(6):1061-5. Available from: http://ndt. oxfordjournals.org/cgi/doi/10.1093/ndt/gfg252

5. ShengK,Zhang P,Chen L, ChengJ,Wu C, ChenJ. Intradialytic Exercise in Hemodialysis Patients: A Systematic Review and Meta-Analysis. Am J Nephrol [Internet]. 2014;40(5):478-90. Available from: http://www.karger. com?doi=10.1159/000368722

6. Marcus RL, LaStayo PC, Ikizler TA, Wei G, Giri A, Chen X, Morrell G, Painter P, Beddhu S. Low Physical Function in Maintenance Hemodialysis Patients Is Independent of Muscle Mass and Comorbidity. J Ren Nutr [Internet]. 2015 Jul;25(4):371-5. Available from: http://linkinghub.elsevier.com/retrieve/pii/ S1051227615000436

7. Xavier VB, Roxo RS, Miorin LA, dos Santos Alves VL, dos Santos Sens YA. Impact of continuous positive airway pressure (CPAP) on the respiratory capacity of chronic kidney disease patients under hemodialysis treatment. Int Urol Nephrol [Internet]. 2015 Jun 30;47(6):10116. Available from: http://link.springer.com/10.1007/ s11255-015-0988-y

8. Cury JL, Brunetto AF, Aydos RD. Negative effects of chronic kidney failure on lung function and functional capacity. Rev Bras Fisioter [Internet]. 2010;14(2):918. Available from: http://www.ncbi.nlm.nih.gov/ pubmed/20464163

9. Jette AM. Toward a common language for function, disability, and health. Phys Ther [Internet]. 2006 May;86(5):726-34. Available from: http://www.ncbi. nlm.nih.gov/pubmed/16649895
10. Castaneda L, Bergmann A, Bahia L. The International Classification of Functioning Disability and Health: asystematic review of observational studies. Rev Bras Epidemiol [Internet]. 2014 Jun;17(2):437-51. Available from: http://www.scielo. br/scielo.php?script=sci_arttext\&pid=S1415-790X201400 0200437\&lng=en\&nrm=iso\&tlng=en

11. WHO. WHO International Classification of Functioning, Disability and Health (ICF). Geneva: World Health Organization - WHO; 2001.

12. World Health Organization. WHO Psychiatric disability schedule (WHO/DAS) [Internet]. Geneva: World Health Organization-WHO; 1988.96 p. Available from: http://apps. who.int/iris/bitstream/10665/40429/1/9241561114.pdf

13. Wiersma D, DeJong A, Ormel J. The Groningen Social Disabilities Schedule: development, relationship with I.C.I.D.H., and psychometric properties. Int J Rehabil Res [Internet]. 1988;11(3):213-24. Available from: http:// www.ncbi.nlm.nih.gov/pubmed/2978514

14. Üstün TB, Chatterji S, Kostanjsek N, Rehm J, Kennedy C, Epping-Jordan J, Saxena S, von Korff M, Pull C. Developing the World Health Organization Disability Assessment Schedule 2.0. Bull World Health Organ [Internet]. 2010 Nov 1;88(11):815-23. Available from: http://www.who. int/bulletin/volumes/88/11/09-067231.pdf

15. Üstün T, Kostanjsek N, Chatterji S, Rehm J. Measuring health and disability: Manual for WHO disability assessment schedule WHODAS 2.0 [Internet]. Üstün T, Kostanjsek N, Chatterji S, Rehm J, editors. Geneva: World Health Organization - WHO; 2010 [cited 2014 Mar 27]. 152 p. Available from: http://apps.who.int/iris/ bitstream/10665/43974/1/9789241547598_eng.pdf

16. Castro SS, Leite CF, Osterbrock C, Santos MT, Adery R. Avaliação de Saúde e Deficiência: Manual doWHO Disability Assessment Schedule (WHODAS 2.0) [Internet]. Uberaba: Universidade Federal do Triângulo Mineiro - UFTM; 2015. 153 p. Available from: http://apps.who.int/iris/ bitstream/10665/43974/19/9788562599514_por.pdf

17. Maher C, Latimer J, Costa L. The relevance of cross-cultural adaptation and clinimetrics for physical therapy instruments. Rev Bras Fisioter [Internet]. 2007 Aug;11(4):245-52. Available from:http://www.scielo.br/scielo.php?script=sci arttext\&pid=S1413-35552007000400002\&lng=en\&nrm= iso\&tlng=en 
18. Garin O, Ayuso-Mateos JL, Almansa J, Nieto M, Chatterji S, Vilagut G, et al. Validation of the "World Health Organization Disability Assessment Schedule, WHODAS-2" in patients with chronic diseases. Health Qual Life Outcomes [Internet]. 2010 Jan [cited 2014 Mar 27];8:51. Available from: http://www. pubmedcentral.nih.gov/articlerender.fcgi?artid=28 93517\&tool=pmcentrez\&rendertype=abstract

19. Kutlay S, Küçükdeveci A a, Elhan AH, Oztuna D, Koç N, Tennant A. Validation of the World Health Organization disability assessment schedule II (WHODAS-II) in patients with osteoarthritis. Rheumatol Int [Internet]. 2011 Mar [cited 2014 Mar 27];31(3):33946. Available from: http://www.ncbi.nlm.nih.gov/ pubmed/20020133

20. Baron M, Schieir O, Hudson M, Steele R, Kolahi S, Berkson $\mathrm{L}$, et al. The clinimetric properties of the world health organization disability assessment schedule II in early inflammatory arthritis. Arthritis Rheum [Internet]. 2008 Mar 15;59(3):382-90. Available from: http://doi.wiley. com/10.1002/art.23314

21. Meesters JJL, Verhoef J, Liem ISL, Putter H, Vliet Vlieland TPM. Validity and responsiveness of the World Health Organization Disability Assessment Schedule II to assess disability in rheumatoid arthritis patients. Rheumatology [Internet]. 2010 Feb 1;49(2):326-33. Available from: http://www.rheumatology.oxfordjournals.org/cgi/ doi/10.1093/rheumatology/kep369

22. Magistrale G, Pisani V, Argento O, Incerti CC, Bozzali M, Cadavid D, Caltagirone C, Medori R, DeLuca J, Nocentini U. Validation of the World Health Organization Disability Assessment Schedule II (WHODAS-II) in patients with multiple sclerosis. Mult Scler [Internet]. 2015 Apr 1;21(4):448-56. Available from: http://msj. sagepub.com/cgi/doi/10.1177/1352458514543732

23. Hudson M, Steele R, Taillefer S, Baron M. Quality of life in systemic sclerosis: psychometric properties of the World Health Organization Disability Assessment Schedule II. Arthritis Rheum [Internet]. 2008 Feb 15 [cited 2014 Mar 27];59(2):270-8. Available from: http://www.ncbi.nlm. nih.gov/pubmed/18240187
24. Carlozzi NE, Kratz AL, Downing NR, Goodnight S, Miner JA, Migliore N, Paulsen JS. Validity of the 12-item World Health Organization Disability Assessment Schedule 2.0 (WHODAS 2.0) in individuals with Huntington disease (HD). Qual Life Res [Internet]. 2015 Aug 31;24(8):196371. Available from: http://link.springer.com/10.1007/ s11136-015-0930-x

25. Guilera G, Gómez-Benito J, Pino 0, Rojo JE, Cuesta MJ, Martínez-Arán A, et al. Utility of the World Health Organization Disability Assessment Schedule II in schizophrenia. Schizophr Res [Internet]. 2012 Jul;138(23):240-7. Available from: http://linkinghub.elsevier. com/retrieve/pii/S0920996412001843

26. Guilera G, Gómez-Benito J, Pino Ó, Rojo E, Vieta E, Cuesta MJ, et al. Disability in bipolar I disorder: The 36-item World Health Organization Disability Assessment Schedule 2.0. J Affect Disord [Internet]. 2015;174:35360. Available from: http://linkinghub.elsevier.com/ retrieve/pii/S0165032714008143

27. Schlote A, Richter M, Wunderlich MT, Poppendick U, Möller C, Schwelm K, et al. WHODAS II with people after stroke and their relatives. Disabil Rehabil [Internet]. 2009 Jan [cited 2014 Mar 27];31(11):855-64. Available from: http://www.ncbi.nlm.nih.gov/pubmed/19093276

28. Pösl M, Cieza A, Stucki G. Psychometric properties of the WHODASII in rehabilitation patients. Qual Life Res [Internet]. 2007 Nov [cited 2014 Mar 27];16(9):1521-31. Available from: http://www.ncbi.nlm.nih.gov/pubmed/17828578

29. Chisolm TH. The WHO-DAS II: Psychometric Properties in the Measurement of Functional Health Status in Adults With Acquired Hearing Loss. Trends Amplif [Internet]. 2005 Sep 1 [cited 2014 Mar 27];9(3):11126. Available from: http://tia.sagepub.com/cgi/ doi/10.1177/108471380500900303

30. Skevington SM, Lotfy M, O'Connell KA, WHOQOL Group. The World Health Organization's WHOQOL-BREF quality of life assessment: psychometric properties and results of the international field trial. A report from the WHOQOL group. Qual Life Res [Internet]. 2004 Mar;13(2):299-310. Available from: http://www.ncbi. nlm.nih.gov/pubmed/15085902 
31. Gholami A, Jahromi LM, Zarei E, Dehghan A. Application of WHOQOL-BREF in Measuring Quality of Life in Health-Care Staff. IntJPrev Med[Internet]. 2013 Jul;4(7):809-17.Available from: http://www.ncbi.nlm.nih.gov/pubmed/24049600

32. The WHOQOL Group. The World Health Organization Quality of Life assessment (WHOQOL): position paper from the World Health Organization. Soc Sci Med [Internet]. 1995 Nov;41(10):1403-9. Available from: http://www.ncbi.nlm.nih.gov/pubmed/8560308

33. Fleck MP, Louzada S, Xavier M, Chachamovich E, Vieira G, Santos L, Pinzon V. Aplicação da versão em português do instrumento abreviado de avaliação da qualidade de vida "WHOQOL-bref". Rev Saude Publica [Internet]. 2000 Apr [cited 2015 Jan 8];34(2):178-83. Available from: http://www.scielo.br/scielo.php?script=sci_ arttext\&pid=S0034-89102000000200012\&lng=pt\&n

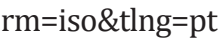

34. Joshi VD, Mooppil N, Lim JF. Validation of the Kidney Disease Quality of Life-Short Form: a cross-sectional study of a dialysis-targeted health measure in Singapore. BMC Nephrol [Internet]. 2010;11(1):36. Available from: http://www.biomedcentral.com/1471-2369/11/36

35. Tao X, Chow SK, Wong FK. Determining the validity and reliability of the Chinese version of the Kidney Disease Quality of Life Questionnaire (KDQOL-36TM). BMC Nephrol [Internet]. 2014;15(1):115. Available from: http://www.biomedcentral.com/1471-2369/15/115

36. Abd ElHafeez S, Sallam SA, Gad ZM, Zoccali C, Torino C, Tripepi G, ElWakil HS, Awad NM. Cultural adaptation and validation of the "Kidney Disease and Quality of Life - Short Form (KDQOL-SFTM) version 1.3" questionnaire in Egypt. BMC Nephrol [Internet]. 2012;13(1):170. Available from: http://www.biomedcentral.com/1471-2369/13/170
37. Duarte PS, Ciconelli RM, Sesso R. Cultural adaptation and validation of the "Kidney Disease and Quality of Life--Short Form (KDQOL-SF 1.3)" in Brazil. Braz J Med Biol Res [Internet]. 2005 Feb;38(2):261-70. Available from: http://www.ncbi.nlm.nih.gov/ pubmed/15785838

38. Cronbach LJ. Coefficient alpha and the internal structure of tests. Psychometrika [Internet]. 1951 Sep;16(3):297334. Available from: http://link.springer.com/10.1007/ BF02310555

39. Tate RL, Godbee K, Sigmundsdottir L. A systematic review of assessment tools for adults used in traumatic brain injury research and their relationship to the ICF. NeuroRehabilitation. 2013;32(4):729-50.

40. Thonnard JL, Penta M. Functional assessment in physiotherapy. A literature review. Eura Medicophys [Internet]. 2007 Dec 15;43(4):525-41. Available from: http://www.ncbi.nlm.nih.gov/pubmed/5764933

41. Moen VP, Drageset J, Eide GE, Klokkerud M, Gjesdal S. Validation of World Health Organization Assessment Schedule 2.0 in specialized somatic rehabilitation services in Norway. Qual Life Res [Internet]. 2016 Aug 9; Available from: http://link.springer.com/10.1007/ s11136-016-1384-5

42. Cheung MKT, Hung ATF, Poon PKK, Fong DYT, Li LSW, Chow ESL, Qiu Z-Y, Liou T-H. Validation of the World Health Organization Assessment Schedule II Chinese Traditional Version (WHODAS II CT) in persons with disabilities and chronic illnesses for Chinese population. Disabil Rehabil [Internet]. 2015 Sep 25;37(20):1902-7. Available from: http://www.tandfonline.com/doi/full/ 10.3109/09638288.2014.989336 
43. Kutlay Ş, Küçükdeveci AA, Elhan AH, Öztuna D, Koç N, Tennant A. Validation of the World Health Organization disability assessment schedule II (WHODAS-II) in patients with osteoarthritis. Rheumatol Int [Internet]. 2011 Mar 18;31(3):339-46. Available from: http://link. springer.com/10.1007/s00296-009-1306-8

44. Chiu T-Y, Yen C-F, Chou C-H, Lin J-D, Hwang A-W, Liao H-F, Chi W-C. Development of traditional Chinese version of World Health Organization Disability Assessment Schedule 2.036 - item (WHODAS 2.0) in Taiwan: Validity and reliability analyses. Res Dev Disabil [Internet]. 2014 Nov;35(11):2812-20. Available from: http://linkinghub. elsevier.com/retrieve/pii/S0891422214002790
45. Wolf AC, Tate RL, Lannin NA, Middleton J, Lane-Brown A, Cameron ID. The World Health Organization Disability Assessment Scale, WHODAS II: reliability and validity in the measurement of activity and participation in a spinal cord injury population. J Rehabil Med [Internet]. 2012 Sep [cited 2015 Jan 8];44(9):747-55. Available from: http://www.ncbi.nlm.nih.gov/pubmed/22854805

46. Andresen EM. Criteria for assessing the tools of disability outcomes research. Arch Phys Med Rehabil [Internet]. 2000 Dec;81(12 Suppl 2):S15-20. Available from: http:// linkinghub.elsevier.com/retrieve/pii/S0003999300226324

Received in 12/04/2017

Recebido em 04/12/2017

Recibido en 04/12/2017

Approved in 05/29/2018

Aprovado em 29/05/2018

Aprobado en 29/05/2018, 